This item was submitted to Loughborough's Research Repository by the author.

Items in Figshare are protected by copyright, with all rights reserved, unless otherwise indicated.

\title{
State before Partition: India's Interim Government under Wavell
}

PLEASE CITE THE PUBLISHED VERSION

https://doi.org/10.1080/00856401.2019.1556890

PUBLISHER

Taylor \& Francis (Routledge) @ South Asian Studies Association of Australia

VERSION

AM (Accepted Manuscript)

PUBLISHER STATEMENT

This is an Accepted Manuscript of an article published by Taylor \& Francis in South Asia: Journal of South Asian Studies on 3 February 2019, available online:

http://www.tandfonline.com/10.1080/00856401.2019.1556890.

\section{LICENCE}

CC BY-NC-ND 4.0

\section{REPOSITORY RECORD}

Ankit, Rakesh. 2019. "State Before Partition: India's Interim Government Under Wavell”. Loughborough University. https://hdl.handle.net/2134/36462. 


\title{
State before Partition: India's Interim Government under
}

\section{Wavell}

\begin{abstract}
This paper is a study of the Interim Government in British India, formed during the penultimate viceroyalty of Archibald Wavell, from September 1946 to March 1947. It tries to throw light on major and minor personalities and micro and macro processes at work in this improbable interlude and, thus, probes an over-shadowed ministerial and bureaucratic set-up in the leadup to Partition. This under-studied set-up constituted yet another compelling 'space before Partition' activities wherein would continue to affect the Indian state after Partition. Simultaneously, it seeks to complicate the teleology and inevitability of Partition by showing this interim arrangement at work, which belied its name. Bringing together official texts and personal interpretations of many participants, it approaches the period as liminal albeit one with limitless possibilities at this juncture, of which what followed in 1947 was but one.
\end{abstract}

\section{Keywords}

Archibald Wavell; British India; Interim Government; Partition

\section{Introduction}


I wonder if any country ever had a government like the Congress-Muslim League coalition, which ruled India from October 1946 to August 1947. We functioned like a little parliament... On matters of day-to-day administration, there was seldom any difference... ${ }^{1}$

Thus wrote Dr. John Matthai, a prominent non-Congress, non-League member of that government called the Interim Government. And yet, it remains among the least studied aspects of pre-Partition India. Appearing too late in the imperial phase and ascribed as a strawman for independence and Partition, it has been rendered remote in the recent history-writing on contemporary sub-continent. ${ }^{2}$ While at one time the Interim Government was used for dialectical purposes by scholars of endgames of empire, the struggle for independence, the origins of Partition and the demand for Pakistan, subsequent strands of scholarship on provinces, localities and memories around 1947 had minimal use for it. ${ }^{3}$ The latest trend of studying the Indian and Pakistani states, as they emerged from the long shadow of 1947, confines it to being a drop-curtain or a curtain-raiser. ${ }^{4}$ This evasion of the Interim Government, especially its six months under the viceroyalty of Archibald Wavell, hints at, if anything, its elusive nature and the need to take a closer look at it, using diverse sources. Seeking to do that, this article argues that it is erroneous to look upon the Interim Government only through the prism of Partition. In its own way, it was a moment of political accommodation, in the transition from empire to dominions in British India. Confronting social divisions and economic crises and coexisting with the colonial state-apparatus, its personalities, priorities and policies, related

\footnotetext{
${ }^{1}$ Unpublished manuscript, Dr. John Matthai Papers, Acc. no. R-10824 (microfilm), pp. 1-8, Nehru Memorial Museum and Library (hereafter NMML).

${ }^{2}$ An exception is Muhammad Iqbal Chawla, 'The Interim Government in India in 1946-47: A Fresh Light', in Journal of the Pakistan Historical Society, Vol. 62, no. 2 (2014), pp. 7-32 and Wavell and the Dying Days of the Raj: Britain's Penultimate Viceroy in India (Karachi: OUP, 2012), albeit in relation to Partition, as an 'irony'. See Anirudh Deshpande, 'Review of Chawla, Mohammad Iqbal, Wavell and the Dying Days of the Raj: Britain's Penultimate Viceroy in India', H-Asia, H-Net Reviews. January, 2014 [http://www.h-net.org/reviews/showrev.php?id=37909 accessed 17 May 2018].

${ }^{3}$ See Ian Talbot and Gurharpal Singh (eds.), The Partition of India (Cambridge: CUP, 2009).

${ }^{4}$ See Vazira Fazila-Yacoobali Zamindar, The Long Partition and the Making of Modern South Asia: Refugees, Boundaries, Histories (New York: Columbia University Press, 2010) and Taylor Sherman, William Gould and Sarah Ansari (eds.), From Subjects to Citizens: Society and the Everyday State in India and Pakistan, 1947-70 (Cambridge: CUP, 2014).
} 
to post-war reconstruction, deserve a look beside the politics of Partition. That tense relationships between the Indians and the Britons, the Congress and the League and the politicals and the officials bedevilled the Interim Government, the State before Partition, makes its beleaguered existence more and not less remarkable. Subsequent readings of, and from the vantage of, Partition, have shrouded any pursuits of its 'pure particular', poised with possibilities - not all unrealized - and persistent with continuities - quite a few prolonged; what Paul Schroeder described as 'seeing them from the inside through empathetic understanding'.5

The seeds of the Interim Government were contained in the idea of the expansion and Indianisation of viceroy's executive council under consideration well before the end of the Second World War. ${ }^{6}$ However, it could only be broadcast publicly in the aftermath of 'the wartime shift of mood'. ${ }^{7}$ Since the failure of the 1942 Cripps Mission, the subsequent launch of Congress' Quit India movement and the consequent imprisonment of its leadership, Britain's Indian problem had been brewing. ${ }^{8}$ The growth of the Muslim League and activities of the now-legalised Communist Party of India only enhanced it. Thus, the June 1945 Simla Conference, sanctioned by the British Conservative Prime Minister Winston Churchill and Secretary of State for India Leo Amery, and the February-June 1946 Cabinet Mission, sent by their Labour successors, Clement Attlee and Pethick-Lawrence were both responses to deteriorating circumstances. ${ }^{9}$ The Interim Government was the first among the few outcomes of the Cabinet Mission. Its proposed three-tier system of government, with a union of India to

\footnotetext{
${ }^{5}$ Paul Schroeder, 'History and International Relations Theory: Not Use or Abuse, but Fit or Misfit', in International Security, Vol. 22, no. 1 (1997), pp. 64-74, p. 66.

${ }^{6}$ On Wavell's role, see Victoria Schofield, Wavell: Soldier \& Statesman (London: Pen \& Sword, 2010).

${ }^{7}$ Kenneth Morgan, Labour in Power: 1945-1951 (Oxford: OUP, 1984), p. 20.

${ }^{8}$ See R.J. Moore, Escape from Empire: The Attlee Government and the Indian Problem (Oxford: Clarendon Press, 1983).

${ }^{9}$ On the Cabinet Mission, see Peter Clarke, The Cripps Version (London: Allen Lane, 2002).
} 
deal with foreign affairs, defence, communications, and relevant areas of finance', ${ }^{10}$ and seemingly vindicated Wavell, who had 'tried hard to persuade [the Indians] that real communal issues often do not arise in practical administration'. ${ }^{11}$ To Matthai too, it represented a 'recognition on the part of the Congress that the main problems facing the country were not political in character but were concerned with daily needs'. ${ }^{12}$ This creed of political acceptance and power accommodation - howsoever liminal and limited - is highlighted by this paper, much as it heralded the establishment of the Interim Government. In the victorious aftermath of the elections of winter 1945-6, in which it took office in eight out of eleven provinces, and amidst the deteriorating communal climate of summer 1946, an arrangement that 'was to work on communal representation' was less than grudgingly accepted by the Congress high command. And, when faced 'with the fait accompli of a functioning government', the Muslim League acquiesced in it. ${ }^{13}$

This spirit was reflected in the reconstitution of viceroy's executive council, which its incoming Indian members wished to call cabinet, ${ }^{14}$ whose leading personalities were the Congress' big five - Jawaharlal Nehru, Vallabhbhai Patel, Abul Kalam Azad, Rajendra Prasad and Chakravarti Rajagopalachari - and the League's nominees - Liaquat Ali Khan, Ibrahim Ismail Chundrigar, Abdur Rab Nishtar, Ghazanfar Ali Khan and Jogendra Nath Mandal. They were joined by Matthai, Baldev Singh and Cooverji Hormusji Bhabha, representatives of Christians, Sikhs and Parsis, respectively, in what can be called an elite, 'consociational'

\footnotetext{
${ }^{10}$ Morgan, Labour in Power, p. 222.

${ }^{11}$ Wavell to Attlee, 1 Aug. 1946, PREM 8/554, The National Archives (henceforth TNA).

${ }^{12}$ Matthai manuscript, pp. 1-8, NMML.

${ }^{13}$ Benjamin Zachariah, Nehru (London: Routledge, 2004), pp. 131-2.

${ }^{14}$ Wavell to Pethick-Lawrence, 10 Sept. 1946, L/PO/10/23, India Office Records, British Library (henceforth IOR).
} 
collection. ${ }^{15}$ Consociationalism, a 'power-sharing system' applied to post-1947 India with its representative coalition, proportional civil service, federal autonomy and provincial ministries, can be utilised to understand the immediately pre-1947 India too. ${ }^{16}$ This attempt to avoid bitterness and create an atmosphere conducive to cooperation' was neither easy nor did it last but that does not mean that it was not there. ${ }^{17}$ It is this process of accord, whose working out - howsoever little and late - is annotated by this paper, as it was attempted in the Interim Government. Rajagopalachari, for instance, would urge his party men in the central legislature to sit 'openly behind government bench' and support the coalition. ${ }^{18}$ It was necessary too, given the 'fear of labour militancy' and 'popular politics' among the colonial state and national leadership alike; ${ }^{19}$ similar spots on both the 'setting sun' and 'rising sun' in India in the interim. ${ }^{20}$ These spots, which are sought to be lit in the narrative that follows, congealed around the following themes: (a) food and cloth provision, (b) trade, tariff and taxes, (c) troop movement and labour welfare, and, (d) education, investment and infrastructure.

\section{September-October 1946: Strains, Stresses and Skirmishes}

The day before it was formed on 2 September 1946, Nehru wrote to Wavell that the Interim Government, 'though within the terms of the existing law, [was] in nature and formation

\footnotetext{
${ }^{15}$ See Ian Talbot, 'Back to the future? The Punjab Unionist model of consociational democracy for contemporary India and Pakistan', in International Journal of Punjab Studies, Vol. 3, no. 1 (1996), pp. 65-73.

${ }^{16}$ Arend Lijphart, 'the Puzzle of Indian Democracy: A Consociational Interpretation', in The American Political Science Review, Vol. 90, no. 2 (1996), pp. 258-68, pp. 258-9.

${ }^{17}$ Gadgil to Rajagopalachari, 19 Oct. 1946, Subject File No. 39, C. Rajagopalachari Papers (V Instalment), NMML.

${ }^{18}$ Rajagopalachari to Gadgil, 21 Oct. 1946, Subject File No. 39, Rajagopalachari Papers (V Instalment), NMML.

${ }^{19}$ Sumit Sarkar, 'Popular Movements and National Leadership, 1945-47', in Economic and Political Weekly, Vol. 17, no. 14/16 (1982), pp. 677-689, p. 682-ii.

${ }^{20}$ S.D. Nargolwala, 'Civil Servants had to be Generalists and Specialists', in Raj K. Nigam (ed.), Memoirs of Old Mandarins of India (New Delhi: Documentation Centre for Corporate \& Business Policy Research, 1985), p. 243.
} 
different from its predecessors'. In agreement, Wavell enhanced the status of the incoming members by dispensing with 'the practice of [senior civil servants] having [direct] access to the Viceroy'. ${ }^{21}$ It was clear to both that the old order was being displaced, even if its successor was not yet clear to either. The first file that Wavell received from his new council was about South Africa from Nehru. On the touchy topic of the treatment of Indians there, PethickLawrence had written that the South African government 'might be persuaded [for] a new agreement [if New Delhi] would drop their reference to the United Nations [UN]'. ${ }^{22}$ Now, the new External Affairs and Commonwealth Relations Member was 'quite definite' that he would not approach Prime Minister General Jan Smuts thus. ${ }^{23}$ In London, Nehru's conviction fed Foreign Minister Ernest Bevin's concerns about his readiness 'to accept a measure of United Kingdom [UK] control in foreign affairs'. ${ }^{24}$ In June 1946, Bevin had got a note prepared on the 'situation in India and its possible effects upon Foreign Relations' with Russia, Arab States, Egypt and Persia, Far-East and Indonesia and, above all, withdrawal of Indian troops from abroad. $^{25}$

The first cabinet meeting of the Interim Government took place on 4 September 1946 and, in Wavell's words, went 'smoothly and reasonably'. ${ }^{26}$ Some of the first substantial problems that attracted the cabinet's attention were all issues that would plague the post-1947 Nehru government. These were food policy, especially the question of imports from near (Burma) and far (Argentina, Canada and Australia); troop's policy, chiefly the presence of Indian troops from Indonesia to Iraq; trade policy, basically the question of import duties and

\footnotetext{
${ }^{21}$ Nehru to Wavell and Wavell's note, 1 Sept. 1946, item nos. 237 and 238, in Nicolas Mansergh, E.W.R. Lumby and Penderel Moon (eds.) The Transfer of Power 1942-7 (hereafter TOP) Volume VIII (London: HMSO, 1979), pp. 380-4.

22 Pethick-Lawrence to Wavell, 21 Aug. 1946, L/PJ/8/305, IOR, BL.

${ }^{23}$ Wavell to Pethick-Lawrence, 3 Sept. 1946, L/PO/10/23, IOR, BL.

${ }^{24}$ Cabinet CM (46) $79^{\text {th }}, 4$ Sept. 1946, L/PS/12/4631, IOR, BL.

2514 June 1946, FO 371/59778, TNA.

${ }^{26}$ Penderel Moon (ed.), Wavell: The Viceroy's Journal (London: OUP, 1973), 4 Sept. 1946, p. 346.
} 
export charges and the preparation and passage of a bribery and corruption bill. Above all, as Rajagopalachari impressed upon Ram, 'we must step up production... The distress in regard to food and clothing calls for [it]'. ${ }^{27}$ Among his new colleagues, the Labour Member Jagjivan Ram impressed Wavell with his grasp of the contentious subjects under his department like the 'resettlement of soldiers, labour unrest, [and] position of the Scheduled Castes', while Matthai, whom Wavell considered 'the most capable and intelligent of Ministers', informed the viceroy about India's greatly deteriorated financial position and the consequent 'serious danger of inflation'. ${ }^{28}$ Matthai's presence in the interim cabinet, holding the crucial portfolio of finance, was a result of Nehru inviting him, given his experience in 'administration, business and economics' and his being from a minority community that provided the political justification. ${ }^{29}$ In releasing him, J.R.D. Tata, Matthai's employer, claimed to be 'indirectly contributing to this great purpose'. ${ }^{30}$ Under Matthai and later Liaquat, the Finance Department fashioned an economic policy around the five pillars of inflation, taxation, borrowing, balances and foreign exchange. ${ }^{31}$

Personalities apart, the Interim Government also had an eclectic institutional inheritance and this bureaucratic apparatus did not remain external to its new political masters but came to be entwined with it. ${ }^{32}$ In this, like much else, this interregnum foretold the early Nehruvian regime. For instance, the critical Labour Department had been bifurcated into labour and works, mines and power. While the former had the Indian Shamaldharee Lal [Indian Civil

\footnotetext{
${ }^{27}$ Rajagopalachari to Ram, 12 Sept. 1946, Subject File No. 39, Rajagopalachari Papers (V Instalment), NMML.

${ }^{28}$ Moon (ed.), Wavell, 13 and 17 Sept. 1946, pp. 350-1.

${ }^{29}$ Matthai manuscript, pp. 1-8, NMML.

${ }^{30}$ Tata to Matthai, 3 Sept. 1946, Matthai Papers, Acc. no. R-10824, NMML.

${ }^{31}$ S. Jagannathan to Tarlok Singh, 18 Sept. 1946, File No. 17 (38)/48-PMS, National Archives of India (henceforth NAI).

${ }^{32}$ See Rotem Geva, 'The Scramble for Houses: Violence, a factionalized state, and informal economy in post-partition Delhi', in Modern Asian Studies, Vol. 51, issue 3 (2017), pp. 769-824.
} 
Service (ICS), 1919] as the secretary, the latter had the English ICS HC Prior heading the bureaucracy.. ${ }^{33}$ Lall had been with the Labour Department since 1944, serving Dr. B.R. Ambedkar, before Jagjivan Ram. He was instrumental in the establishment of civil pioneer corps, employment exchanges, labour health insurance and miners' provident fund. Started as a response to war-time demands and shepherded by Ambedkar, each of these continued under the Interim Government. Lall, 'apprehensive to [Ram's] attitude to the work determined by his [politically opposed] predecessor', was pleasantly surprised when Ram 'dispelled [his] doubts and fears'. ${ }^{34}$ This was despite the fact that while Ambedkar's views were influenced by war exigencies 'demanding a maintenance of 'morale' among workers and a 'peaceful' settlement of disputes with state intervention', Jagjivan Ram emphasised 'maintenance of 'discipline' and 'nationalism' among the workers'. ${ }^{35}$

Conflicts too were an integral part of this institutional inheritance, especially the nature of provincial ministries and role of governors there. Objecting to the conduct of Governor Robert Francis Mudie in Sindh, with respect to the Congress-League jockeying there, Nehru insisted that provincial governors were responsible to the governor-general and 'through him' to the Interim Government. ${ }^{36}$ When Wavell replied that governor-general's control on provincial governors was 'in his personal capacity', Nehru argued that 'in view of the change at the centre...the old position undergoes change'. ${ }^{37}$ George Abell (ICS, 1928), Wavell's private secretary, felt that the Congress seemed to under-appreciate 'the extent of provincial autonomy' in the Government of India Act, 1935, in their first days in government. ${ }^{38}$

\footnotetext{
${ }^{33} 6$ April 1946, File No. F.14/2/46-R, NAI.

${ }^{34}$ Shamaldharee Lall, 'An Indian Civil Servant', in Kewal L. Panjabi (ed.), The Civil Servant in India (Bombay: BVB, 1965), p. 19.

${ }^{35}$ Shivangi Jaiswal, 'Caste and Labour in the Official Discourse of India, 1942-52', in Labour \& Development, Vol. 21, no. 1 (2014), pp. 45-75, pp. 55-6.

${ }^{36}$ Nehru to Wavell, 5 Sept. 1946, item no. 259, TOP, Volume VIII, p. 422.

${ }^{37}$ Nehru-Wavell exchange, 8 Sept. 1946, item nos. 280 and 281, TOP, Volume VIII, pp. 448-9.

${ }^{38}$ George Abell to Wavell, 5 Sept. 1946, item no. 262, TOP, Volume VIII, p. 425.
} 
Anticipating these early exchanges, Pethick-Lawrence had cautioned Wavell that 'our present position in India do not permit of your authority being exercised against the majority of your council except for the...protection of minorities, maintenance of services, foreign treaty engagements'. ${ }^{39}$ The India Office followed up with a circular reminding various departments that 'it is His Majesty's Government's [HMG] declared intention to treat the Interim Government as if it were... a Dominion'. ${ }^{40}$

Adding to the uneasy coexistence, were the workings of Defence and Foreign (Political) Departments. Nehru had been feeling aggrieved that his desire for the "withdrawal of Indian troops' from overseas, especially Burma, Indonesia and Iraq, had prompted little response from the Commander-in-Chief Claude Auchinleck. He was further annoyed when a request was made, bypassing him and Defence Member Baldev Singh, on behalf of the Interim Government to London, to 'retain British troops [in India] for a longer period'. In a cabinet meeting on 18 September 1946, Nehru urged Wavell to inform London 'of our feeling that Indian troops should not be used against Burmans and, in any case, not for the suppression of industrial strikes or political movement'. When Wavell tried to deflect this by bringing up the 'considerable number of Indians in Burma [who] have to be given protection'. Nehru responded by broadening the question and asking for an examination of 'the larger quantities of Indian troops being sent abroad for various purposes'. ${ }^{41}$ He complained to Wavell that it was 'difficult to function in the dark' about Defence and Foreign (Political) Departments; the latter looked after the princely states. ${ }^{42}$ His difficult visit to the tribal areas in October, however, saw him admit that 'at the present moment... it would not be right to consider any

\footnotetext{
${ }^{39}$ Pethick-Lawrence to Wavell, 6 Sept. 1946, L/PO/10/26, IOR, BL.

${ }^{40}$ Monteath's note, 16 Sept. 1946, L/PJ/7/4933, IOR, BL.

${ }^{41} 18$ Sept. 1946, File No. 114/CF/46, NAI.

${ }^{42}$ Wavell to Pethick-Lawrence, 18 Sept. 1946, L/WS/1/1052, IOR, BL.
} 
basic changes in the Frontier'. ${ }^{43}$ In turn, the India Office worried about Nehru's 'intention to secure control of paramountcy during the interim period', and cautioned Wavell about 'interference in [princely] states by interim government'. ${ }^{44}$

The number of Indian troops serving outside in September 1946 show the extent of challenge for Nehru and concern for London: Japan $(11,400)$, Hong Kong $(5,800)$, Malaya $(59,000)$, Burma (78,500), Siam (4,000), Borneo (1,000), Ceylon $(1,500)$, Iraq $(16,000)$, Middle-East $(12,500)$ and Italy $(400) .{ }^{45}$ Nehru wrote to Stafford Cripps, the India-hand in Attlee's cabinet, reminding him that 'the one thing that is absolutely necessary is for people to realise that we are not just caretakers for a brief period'. ${ }^{46}$ The India Office put it in another way: 'Important that India is worthily represented abroad and not as a vote in Britain's pocket... why [should] Indian troops be used in Indonesia as peacemakers for the Dutch...why is it a part of India's duties to police Iraq... ${ }^{47}$ The withdrawal of Indian troops from Indonesia was also related to the question of importing rice from there and, approaching PethickLawrence directly, Nehru warned him that 'it would be unfortunate if impression were to gain that HMG preferred to risk starvation in India rather than take negligible military risks [in] providing transport for rice'. ${ }^{48}$ Consequently, Wavell was urged to make 'liberal concessions in all matters, where it is in any case inevitable'. ${ }^{49}$ Meanwhile, efforts continued to get the Muslim League into the Interim Government. B.N. Rau, a friend of Mohammad Ali Jinnah wrote to the Quaid-e-Azam that

\footnotetext{
${ }^{43}$ Nehru to Olaf Caroe, 16 Nov. 1946, Jawaharlal Nehru (post-1947) Papers, File No. 1, NMML.

${ }^{44}$ 15-29 Nov. 1946, L/PS/13/1830, IOR, BL.

${ }^{45}$ Auchinleck's note, 5 Sept. 1946, PREM 8/541/6, TNA.

${ }^{46}$ Nehru to Cripps, 20 Sept. 1946, CAB 127/143, TNA.

4718 Sept. 1946, L/PS/12/1174, IOR, BL.

${ }^{48}$ Nehru to Pethick-Lawrence, 19 Sept. 1946, L/PO/10/18, IOR, BL.

${ }^{49}$ Pethick-Lawrence to Wavell, 20 Sept. 1946, L/PO/10/23, IOR, BL.
} 
The problems which confront us today are problems which concern Hindus and Muslims alike. In foreign affairs, whether in Indonesia or South Africa or the Middle-East or the NWF, there is no cleavage between Nehru's views and those of the Muslim League; in the domestic sphere, our main problems are putting an end to the fratricidal strife, procuring adequate supplies of food and planning power and irrigation projects. In none of these matters, there is any divergence of interest or policy between Hindus and Muslims... ${ }^{50}$

In the second half of September, new matters of discord emerged. Wavell 'disliked' Nehru's proposal to have his friend V.K. Krishna Menon visit Europe as his 'personal representative' and considered Menon carrying a personal message from Nehru about food to the Soviet Foreign Minister V. Molotov especially 'ill-advised and ill-timed'. ${ }^{51}$ In London, Pethick-Lawrence was busy with his own balancing act. He wanted to protect the 'discretionary powers' of governors and the Viceroy but also thought it 'desirable' on occasions to consult the Interim Government 'on matters falling in that field'. He agreed that Nehru could not see all the important correspondence between the Political Department and the princely states as that would be tantamount to infringing paramountcy during the interim period and yet wanted to invest Nehru's membership with real meaning. He was 'far from happy about the embarrassing Krishna Menon', especially his meeting with Molotov for wheat, but could not persuade the Attlee Cabinet to divert 100,000 tons of Canadian wheat to India. ${ }^{52}$ PethickLawrence was also annoyed when, in mid-October 1946, Nehru directly approached Premier General Aung San over the matter of Indian troops in Burma. ${ }^{53}$ Nehru's reply further illustrates the constrained coexistence of British officialdom and Indian politicals in the realm of external affairs, ${ }^{54}$ during the Interim Government: 'I am not unaware of our relations with HMG. But I do not understand how those relations come in the way of our conferring with the present government of Burma on a common matter of interest'. 55

\footnotetext{
${ }^{50}$ B.N. Rau to Jinnah, 22 Sept. 1946, item no. 350, TOP, Volume VIII, p. 563.

${ }^{51}$ Wavell to Pethick-Lawrence, 23 Sept. 1946, L/PS/12/4045, IOR, BL.

${ }^{52}$ Pethick-Lawrence to Wavell, 4 Oct. 1946, L/PO/10/23, IOR, BL.

${ }^{53}$ Pethick-Lawrence to Wavell, 11 Oct. 1946, L/PO/10/23, IOR, BL.

${ }^{54}$ See Rakesh Ankit, 'In the Twilight of Empire: Two Impressions of Britain and India at the United Nations, 1945-47', in South Asia: Journal of South Asian Studies, Vol. 38, issue 4 (2015), pp. 574-88.

${ }^{55}$ Nehru to Wavell, 11 Oct. 1946, item no. 438, TOP, Volume VIII, pp. 707-8.
} 
In internal affairs, a serious food shortage was now showing with 'more than 15 crores people covered by food rationing schemes', 56 and 'the ascent of the Interim Government cheered the departing imperial administrators, now tasked with overseeing a transition to selfrule'. ${ }^{57}$ The growing disparity between the controlled prices of Indian cotton and the higher prices in foreign markets was discussed by the Industries and Supplies Member Rajagopalachari, Commerce Member Bhabha and Matthai on 4 October 1946. Assisted by Purshotamdas Thakurdas, president of the East India cotton association, they decided that, given 'the existing disparity' and 'to prevent uncertain speculation', 'an export duty should be imposed'. They also agreed to discontinue control over prices of jute and jute goods and to levy an enhanced duty on raw and manufactured Jute. ${ }^{58}$ Rajagopalachari felt that India 'need not be concerned about losing the market abroad...as the war-frightened world is inclined to self-sufficiency'. ${ }^{59}$ At this time, Bhabha penned an ambitious note that envisioned 'long-term industrialisation - tariff policy - trade expansion - commercial intelligence service - overseas reciprocity [and] sanctions against South Africa' ${ }^{60} \mathrm{He}$ and his successor, Chundrigar, would inaugurate India's 'post-war export policy', particularly on cotton, ${ }^{61}$ which was aligned with the Industries and Supplies Department, where Rajagopalachari was laying out broad aspects of 'industrialisation' and 'import control and regulation of essential articles'. ${ }^{62}$ And, Asaf Ali, next door in the Transport Department, was emphasising 'the economic and strategic

\footnotetext{
${ }^{56}$ Statement by Rajagopalachari, 10 Oct. 1946, Subject File No. 39, Rajagopalachari Papers (V Instalment), NMML.

${ }^{57}$ Benjamin Siegel, Hungry Nation: Food, Famine, and the Making of Modern India (Cambridge: CUP, 2018), p. 60.

${ }^{58}$ Notes by Y.N. Sukthankar and K.B. Lall, 19 and 23 Oct. 1946, File No. 75-XXI/46-C\&G, NAI.

${ }^{59}$ Note by Rajagopalachari, 9 Oct. 1946, Subject File No. 39, Rajagopalachari Papers (V Instalment), NMML.

${ }^{60} 11$ Oct. 1946, L/PJ/10/75, IOR, BL.

${ }^{61}$ Bhabha's note (undated), Oct. 1946, File No. 17 (38)/48-PMS, NAI.

${ }^{62}$ Note by Rajagopalachari, 27 Sept. 1946, Subject File No. 39, Rajagopalachari Papers (V Instalment), NMML.
} 
indivisibility of the entire geographical entity [of] British India and Indian States' (underlined in original). ${ }^{63}$ The figures of Ali's railway budget in early-1947 make for a fascinating reading, given its ambition for track relay and restoration, locomotive and coach construction, road building, anti-slump projects at ports and allotment to the Hindustan Aircrafts Limited.

\section{October-November 1946: A triumvirate Government}

From 12 October, negotiations on portfolios for Muslim League members in the Interim Government dominated the political scene. Jinnah told Wavell that among the big four departments, he desired either the External Affairs or Defence, and was prepared to leave Finance with Matthai. ${ }^{64}$ However, Auchinleck informed Wavell that 'he would prefer Baldev [to] Jinnah'. ${ }^{65}$ Baldev would repay this trust when, in December 1946, he effusively wrote to Attlee that it was 'imperative that Auchinleck remains for 2-3 years' ${ }^{66}$ It was also clear that Nehru did not wish to give up External Affairs. This meant that for the League to get one of the big four, Patel would have to be shifted from Home. ${ }^{67}$ Alongside these political parleys, major structural initiatives continued and the cabinet approved Patel's proposal for a future Indian Administrative Service and Nehru's for its Foreign Service counterpart. ${ }^{68}$ These drew upon Wavell's scheme from August 1946 to refashion future Secretary of State's services. ${ }^{69}$ It was also decided to give effect to Gandhi's pet demand, removal of salt duty, from 1 January 1947. ${ }^{70}$ Rajagopalachari reported that for the second half of 1946 , his department was sending

\footnotetext{
${ }^{63}$ Note by Asaf Ali, 13 Oct. 1946, File No. 17 (38)/48-PMS, NAI.

${ }^{64}$ Wavell's note, 12 Oct. 1946, item no. 435 and Wavell to Pethick-Lawrence, 13 Oct. 1946, item no. 439, TOP, Volume VIII, pp. 704-5, 709.

${ }^{65}$ Moon (ed.), Wavell, 12 Oct. 1946, p. 357.

${ }^{66}$ Baldev Singh to Attlee, 12 Dec. 1946, PREM 8/583, TNA.

${ }^{67}$ Wavell's note, 14 Oct. 1946, item no. 448, TOP, Volume VIII, pp. 721-2.

${ }^{68}$ Wavell to Pethick-Lawrence, 15 Oct. 1946, L/PO/10/23, IOR, BL.

699 Oct. 1946, File No. 127/CF/46, PMS, NAI.

${ }^{70} 15$ Oct. 1946, File No. 131/CF/46, PMS, NAI.
} 
1,520 tons of cloth to Afghanistan, nearly the same to East Africa, 995 tons to Ceylon and 1,700 tons to Burma. ${ }^{71}$

Even as Wavell persisted in his unsuccessful attempts to get Patel to leave Home and accept another portfolio, ${ }^{72}$ he and his Congress colleagues agreed to send a 'first of its kind' Indian delegation to the UN's preparatory committee on trade and employment, and decide that nine Gurkha battalions officered by Indians would be employed in the future Indian Army, while expressing displeasure at the HMG's future employment of the Gurkhas. ${ }^{73}$ In the last week of October 1946, as Wavell now 'tried to persuade [Jinnah and Liaquat] not to insist on Home or Defence', ${ }^{74}$ Congress offered Finance and Commerce to the League, and Jinnah accepted them. ${ }^{75}$ Rajagopalachari spoke for many when he wrote to Cripps that in spite of doubts, people in India on the whole welcome this decision'. ${ }^{76}$ On his part, Wavell ensured that in the order of precedence, the League members do not come at the end, because they had 'entered the government after the others', as was the procedure. ${ }^{77}$

With the coalition finally in place, a cabinet coordination committee was created for outstanding issues like the sterling balance negotiations. Here Wavell was satisfied to learn that both Patel and Liaquat adopted a similarly generous attitude towards London. ${ }^{78}$ On the eve of swearing-in of the League Members, Wavell's thoughts summed up the challenge for the

\footnotetext{
${ }^{71}$ Rajagopalachari to Nehru, 12 Oct. 1946, Subject File No. 39, Rajagopalachari Papers (V Instalment), NMML.

${ }^{72}$ Wavell's note, 16 Oct. 1946, item no. 471, Wavell to Nehru and Wavell's note, 22 Oct. 1946, item nos. 489 and 490, TOP, Volume VIII, pp. 742, 763-4.

${ }^{73}$ Pethick-Lawrence to Wavell, 18 and 30 Oct. 1946, L/PO/10/23, IOR, BL.

${ }^{74}$ Moon (ed.), Wavell, 24 Oct. 1946, pp. 362-3.

${ }^{75}$ See item nos. 494-6, 503-4, 506 and 509, TOP, Volume VIII, pp. 777-85, 800-4.

${ }^{76}$ Rajagopalachari to Cripps, 16 Oct. 1946, Subject File No. 39, Rajagopalachari Papers (V Instalment), NMML.

${ }_{77}$ Abell to Eric Coates, 30 Oct. 1946, File No. F.23 (3)-H/46, PMS, NAI.

${ }^{78}$ See item nos. 527-9, TOP, Volume VIII, pp. 834-8.
} 
interim coalition, formed 'under ominous auspices - riots in East Bengal, restlessness in Bombay and Calcutta, deep mistrust between party leaders... That an agreement has been reached at all is something of an achievement'. ${ }^{79}$ His one hope was that 'things may improve under pressure of events'. Early signs were encouraging: Nehru and Liaquat sat side-by-side in the assembly, and in the bench next to them were Patel, Chundrigar and Asaf Ali. Liaquat had been 'quite sensible' at the press conference after taking oath and, on the first afternoon, Matthai 'backed up a speech by Liaquat on a resolution on Bretton Woods'. ${ }^{80}$ Jinnah had asked his colleagues to work 'for the man in the street' and Liaquat had said, 'nowhere in the world does a Government like the present Interim Government of India exist, and we have come into [it] with the intention of working with our colleagues'. ${ }^{81}$ On 30 October, Wavell chaired the first meeting of the new cabinet in which the chief item was the creation of a consultative committee with princely states. ${ }^{82}$ From London, India Office sent its best wishes, by getting 59,000 tons of cereals from America for the last quarter of $1946 .{ }^{83}$

This cross-communal accommodation could not have been timelier, for the biggest crisis that the interim coalition faced was that of country-wide food shortage. ${ }^{84}$ The Rajendra Prasad-led Food Department responded with schemes to 'conserve food resources', 'intensify food procurement', and, eventually, 'rationing'. ${ }^{85}$ The result was that India had postponed famine without imports for six months, despite a shortage of seven million tonnes of foodgrains. ${ }^{86}$ The second significant arena of work was the Labour Department. Three days after

\footnotetext{
${ }^{79}$ Moon (ed.), Wavell, 25 Oct. 1946, p. 364.

${ }^{80}$ Wavell to Pethick-Lawrence, 30 Oct. 1946, L/PO/10/23, IOR, BL.

${ }^{81}$ Hector Bolitho, Jinnah: Creator of Pakistan (London: John Murray, 1954), p. 168

${ }^{82}$ Moon (ed.), Wavell, 30 Oct. 1946, pp. 367-8.

${ }^{83}$ Pethick-Lawrence to Wavell, 1 Nov. 1946, L/E/8/4120, IOR, BL.

${ }^{84}$ See Sunil Amrith, 'Food and Welfare in India, c. 1900-1950', in Comparative Studies in Society and History, Vol. 50, no. 4 (2008), pp. 1010-35.

${ }^{85}$ See File Nos. RP-1086/2, RP-1000/56 and RP-1085 (Vol. III), Ministry of Food, 1946, NAI.

${ }^{86}$ R.A. Gopalaswami, 'Initiatives and Implementation in ICS', in Nigam (ed.), Memoirs of Old Mandarins of India, p. 83.
} 
Ram assumed its office, he was given a note on 'industrial disputes', which started with 'a wave of strike fever in the country' and suggested a 'political solution': 'a committee to be created of members of Labour, Finance, Industries and Supplies in place of the current 'Industrial Disputes Committee', made of officials, [thus] bureaucratic turf war, and no political leadership'.. ${ }^{87}$ The department also drafted four important legislative measures for the legislative assembly's winter session: (1) Industrial Disputes Bill, (2) an amendment to the Factories Act, (3) Coal Mines Labour Welfare Fund and (4) Workmen's State Insurance. In addition to these, two other bills formerly introduced were re-worked: Minimum Wages Bill and an amendment to the Trade Unions Act. ${ }^{88}$ These were considered necessary because, from before the coming of the Interim Government, there had been a feeling that not only was 'the labour situation becoming increasingly dangerous...it may fall...under Communist and Congress left-wing influence' ${ }^{89}$

\section{November 1946-February 1947: Working Time}

As November 1946 began, Wavell's reports to London usually had 'one cheerful item', which related to the functioning of the interim cabinet; 'not on party lines at all'. ${ }^{90}$ These meetings in New Delhi were in stark contrast to the devastating communal situation in Bengal and Bihar. In the first week of November, Nehru, Liaquat, Patel and Nishtar flew together to Calcutta and Patna and Wavell reflected upon 'this getting together [being] the most hopeful feature of the political situation for a long time'. Upon their return, the cabinet dealt with proposals 'for encouraging small savings, establishment of a Price Fixing Committee, rules for the admission

\footnotetext{
${ }^{87}$ Note by T.H. Burney, 5 Sept. 1946, File No. 17 (38)/48-PMS, NAI.

${ }^{88}$ Note by V.K.R. Menon (undated), October 1946, File No. 127/CF/46-PMS, NAI.

899 Aug. 1946, File No. 12/7/46-Poll (I), Home, NAI.

${ }^{90}$ Wavell to Pethick-Lawrence, 5 Nov. 1946, L/PO/10/23, IOR, BL.
} 
of foreigners into India, instructions to India's UN delegation about trying to secure a seat for India on the Security Council, demobilisation and establishment of a Railway Protection Force'. ${ }^{91}$ In the second week, another cabinet meeting discussed the civil aviation agreement with America. The Americans 'were allowed to operate three routes across India', but New Delhi retained 'control over the capacity of the services'. ${ }^{92}$ Matthai encouraged Wavell by telling him that if the coalition "could keep together for the next month or two it might turn out all right'. ${ }^{93}$ He was now holding the charge of the department of Works, Mines and Power, which did the early work on Damodar, Mahanadi and Kosi river projects, to pave the road to India's post-war industrialisation. ${ }^{94}$

R.N. Banerjee (ICS, 1918), Nehru's secretary in the Commonwealth Relations office, recalled with regret that while 'a great deal has been said on a system of divided responsibility', not a lot on 'inter-ministerial...business of government department[s]'. ${ }^{95}$ As J.M. Lobo-Prabhu (ICS, 1928) put it, 'whoever was on top, the other ranks were engaged as usual with their work'. ${ }^{96}$ In the third week of November, Wavell wrote, after mentioning the 'savage communal violence' in Bengal, Bihar and the United Province (UP) that the cabinet sensibly passed central-help for these provinces. ${ }^{97}$ As the coalition cabinet crossed its first month, Wavell noted, 'if only the leaders were as reasonable outside cabinet as inside it'. ${ }^{98}$ During the winter session of the central assembly too, 'a good deal of business had been transacted'. ${ }^{99}$ In December, while Wavell - along with some Indian leaders - was away in London for a failed

\footnotetext{
${ }^{91}$ Moon (ed.), Wavell, 3 and 6 Nov. 1946, pp. 369-73.

${ }^{92}$ Wavell to Pethick-Lawrence, 13 Nov. 1946, L/PO/10/23, IOR, BL.

${ }^{93}$ Moon (ed.), Wavell, 12 Nov. 1946, p. 376.

${ }^{94}$ Note by B.K. Gokhale, 27 Aug. 1946, File No. 17 (38)/48-PMS, NAI.

${ }^{95}$ Banerjee, 'Three Decades in the ICS', in Nigam (ed.), Memoirs of Old Mandarins of India, p. 19.

${ }^{96}$ Lobo-Prabhu, 'Commitment to Covenant and Country', in Nigam (ed.), Memoirs of Old Mandarins of India, pp. 186-7.

${ }^{97}$ Wavell to Pethick-Lawrence, 22 Nov. 1946, L/PO/10/23, IOR, BL.

${ }^{98}$ Moon (ed.), Wavell, 27 Nov. 1946, p. 383.

${ }^{99} 22$ Nov. 1946, L/PJ/10/76, IOR, BL.
} 
meeting on the future Constituent Assembly, ${ }^{100}$ the officiating John Colville reported that 'in spite of the state of party feeling, all the cabinet meetings [were] correct and peaceful'.. ${ }^{101}$ And, there was some humour too. At a cabinet meeting, Patel said that 'whoever else might resign, he had no intentions [to do so]'.. ${ }^{102}$ Indeed, as B. Shiva Rao, the noted journalist with deep reach in Congress circles reported to the old liberal Tej Bahadur Sapru, 'the transition stage will be longer than we think [and] the interim government must press forward with getting as much power as it can'. ${ }^{103}$ Arguably the biggest concern, as Wavell returned, was the 'famine threat', with Prasad wanting 'Turkish wheat urgently'.. ${ }^{104}$

The first cabinet meeting of 1947 was held on 3 January and discussed the simple matter of jute requisition to pay for grain from Argentina, with the 'stormy' affair of the press ordinance. As Matthai wrote, with reference to press censorship, this was emerging as the principal cause of dispute within the administration of the Home Department. ${ }^{105}$ Next day, the cabinet met again to discuss 'a threatened strike in the Government Presses'. ${ }^{106}$ Soon, Liaquat was preparing budget estimates, and, the cabinet was discussing the report on the Royal Indian Navy mutiny, passing the coal report and raising possibilities of thorium and uranium extraction in Travancore. ${ }^{107}$ From 6 to 18 January, the Asiatic Regional Conference on labour for south-east Asia was held in New Delhi, serving as a precursor to the Asian Relations Conference. ${ }^{108}$ In mid-January, Nehru and Liaquat put their heads together on the question of Indian National Army (INA) personnel's release, control of frontier tribesmen, withdrawal of

\footnotetext{
${ }^{100}$ Ayesha Jalal, The Sole Spokesman: Jinnah, the Muslim League and the Demand for Pakistan (Cambridge: CUP, 1994), p. 234.

${ }^{101}$ Colville to Pethick-Lawrence, 18 and 23 Dec. 1946, L/PO/10/23, IOR, BL.

${ }^{102}$ Colville to Pethick-Lawrence, 10 Dec. 1946, L/PJ/10/76, IOR, BL.

${ }^{103}$ Rao to Sapru, 18 Dec. 1946, Correspondences File, B. Shiva Rao Papers, NMML.

${ }^{104}$ Moon (ed.), Wavell, 2 Jan. 1947, p. 404.

${ }^{105}$ Matthai manuscript, pp. 1-8, NMML.

${ }^{106}$ Moon (ed.), Wavell, 3-4 Jan. 1947, p. 405.

${ }^{107}$ Moon (ed.), Wavell, 8 Jan. 1947, p. 407.

${ }^{108}$ See FO 371/59605, TNA.
} 
British troops from India, and, the Damodar and Mahanadi valley projects. ${ }^{109}$ Wavell noted that the 'Congress [seemed] sobered by responsibility'.. ${ }^{110}$ At this time, with Asaf Ali appointed as India's first ambassador to America, there was another cabinet reshuffle and Abul Kalam Azad entered as Education Member.- ${ }^{111}$ The Education Department, led by Azad, was able to envision Indian education, post-1947, in a five-year plan it laid out, with an impressive educational expenditure outlined in it. Notwithstanding the internal turmoil, international opportunities for students had continued in 1946-47, with over hundred students each sent to United States and United Kingdom supported by the government's overseas scholarships scheme. ${ }^{112}$

The new cabinet met on 15 January and discussed 'the report on planning' - later to serve as a blueprint for independent India's first five-year plan. ${ }^{113}$ The next cabinet meeting saw Baldev Singh recommend the release of all INA men and restoration of their pay for the period, when they were fighting the British in the north-east. The cabinet was united on these concessions and wanted to announce them before 23 January, when Sarat Chandra Bose was holding a meeting in Calcutta in memory of his deceased brother and the INA leader, Subhash. This was one matter on which Wavell, Auchinleck and London were 'firm' in the face of 'Nehru-Liaquat-Baldev's together [ness]'.. ${ }^{114}$ There were other issues too on which they remained together like 'labour trouble, railway and coal strike', as there remained matters in which 'the communal element obtruded itself' like the press ordinance, which the League was convinced was a 'device of Patel's to muzzle Dawn'. ${ }^{115}$ Just as there were limits to the 'freest

\footnotetext{
${ }^{109}$ Wavell to Pethick-Lawrence, 14 Jan. 1947, L/PO/10/24, IOR, BL.

${ }^{110}$ Moon (ed.), Wavell, 9 and 14 Jan. 1947, pp. 409-10.

${ }^{111}$ Wavell to Pethick-Lawrence, 22 Jan. 1947, L/PJ/10/76, IOR, BL.

${ }^{112}$ File No. 3-2/46 (ODI-1946), Education Department, NAI.

${ }^{113}$ Moon (ed.), Wavell, 15 Jan. 1947, p. 411.

${ }^{114}$ Wavell to Pethick-Lawrence, 24 Jan. 1947, L/PJ/10/76, IOR, BL.

${ }^{115}$ Moon (ed.), Wavell, 21 Jan. 1947, p. 413.
} 
possible hand' that Wavell tried to give to his cabinet, so there were limits to 'complete cooperation' between the parties, until 'a settlement [was] arrived on the general political situation'. ${ }^{116}$ But, the cabinet continued to meet and Wavell faced more difficulty in his last months on the combined 'demand for withdrawal of British troops' and the 'INA business', than any inter-Congress-League squabble. Even after the Punjab Unionist Government's banning of the Muslim National Guards and the Rashtriya Swayamsevak Sangh on 24 January 1947, which Wavell expected to produce 'much communalism', the cabinet meetings continued 'in a peaceful atmosphere', passing essential items like rice procurement and wheat import. ${ }^{117}$ Communalism in the country, on the watch of the Interim Government, was queried by A.E.H. Jaffer in the legislative assembly, at this time, and the Home Department produced the following official tally:

Orissa (no riots), Punjab (25 Hindus, 23 Moslems), Ajmer-Merwara (no riots), Sind (no riots), Baluchistan (no riots), Bombay (449 Hindus, 440 Moslems), UP (257 Hindus, 850 Moslems), Assam (no riots), Central Province (no riots), Madras (3 Hindus, 3 Moslems), Delhi (11 Hindus and Sikhs, 19 Moslems), Bihar (272/594 Hindus, 4679/5094 Moslems), Bengal (except Mymensingh and Noakhali, 439 Hindus, 272 Muslims; Mymensingh - 23 Hindus, 71 Moslems, Noakhali - 58 Hindus), NWFP (36 Hindus, 9 Moslems) ${ }^{118}$

An under-siege Home Department was trying to expand police force across provinces, by giving financial assistance to Bengal, Punjab, Bihar, Orissa and the North-West Frontier Province, in light of 'unprecedented communal disturbances, uncertain political future, increased influence of left-wing [and] spate of strikes and agrarian disputes'. ${ }^{119}$ The next political crisis, triggered by the League's rejection of the Constituent Assembly on 1 February 1947, came just as the budget session was beginning. V.P. Menon, the Reforms Commissioner,

\footnotetext{
${ }^{116}$ Wavell to Attlee, 17 Jan. 1947, PREM 8/554, TNA and Wavell to Pethick-Lawrence, 18 Jan. 1947, $\mathrm{L} / \mathrm{PJ} / 10 / 76, \mathrm{IOR}, \mathrm{BL}$.

${ }^{117}$ Moon (ed.), Wavell, $22-24$ and 27-30 Jan. 1947, pp. 414-5.

${ }_{118}$ Riots from 2-9-1946 to 15-1-1947, 27 Feb. 1947, File No. 22/1/47-Poll (I), Home, NAI.

${ }^{119}$ See Subject File No. 10, H.K. Mahtab Papers (I Instalment), NMML.
} 
told Wavell that 'the Partition of India is now inevitable'. ${ }^{120}$ Nehru himself would bring up ‘the question of partitioning Bengal and Punjab' with Wavell and Krishna Menon.- ${ }^{121}$ The Joint Planning Committee chimed in with a despondent note: 'The general situation may appear more satisfactory than it was during most of $1946 \ldots$ but the central government is becoming ineffective'. ${ }^{122}$ The cabinet, however, was still capable of coming together on long-term matters like 'the strength of the post-war Indian army', the budget figures, which showed a deficit of Rs680 million, and an air agreement with the Dutch. ${ }^{123}$ Wavell's 'judgement [was that] neither side [was] really anxious for an open break'.. ${ }^{124}$ This ambiguity is captured in Nehru writing to Azad at this time thus: 'We are now in the midst of a very severe crisis...We should allow matters to rest where they are till we know definitely what is going to happen'.. 125 As regards the 'communal difficulty', it is worth quoting a reply from Rajagopalachari to H.S. Suhrawardy, the League Premier of Bengal, on the question of steel allotment to Bengal: 'There [is no] reason why [communalism] should affect the existing scheme when every stockist, Hindu or Muslim, can sell only to persons [with] permits'.. 126

In mid-February, Wavell met Liaquat to discuss the budget, a key component of which was its allocation for defence. Baldev and Auchinleck had sought Rs1460 million but Liaquat and the Finance Department were offering Rs900 million. Wavell, and the rest of the cabinet, sided with Liaquat and held that India would 'have to speculate on a period of peace'. Finally, the question of the Secretary of State services, their withdrawal and compensation was looming large now. There were nineteen departments in the Government of India in 1947, excluding

\footnotetext{
${ }^{120}$ Moon (ed.), Wavell, 1 and 6 Feb. 1947, pp. 416-8.

${ }^{121}$ Zachariah, Nehru, p. 133.

12231 Jan. 1947, L/PJ/10/77, IOR, BL.

${ }^{123}$ Moon (ed.), Wavell, 8 Feb. 1947, p. 418.

${ }^{124}$ Wavell to Pethick-Lawrence, 9 Feb. 1947, L/PJ/10/77, IOR, BL.

${ }^{125}$ Nehru to Azad, 14 Feb. 1947, Jawaharlal Nehru (post-1947) Papers, File No. 2, NMML.

${ }^{126}$ Rajagopalachari to Suhrawardy, 18 Feb. 1947, Subject File No. 42, Rajagopalachari Papers (V Instalment), NMML.
} 
political and legislative but including the Cabinet Secretariat. Of their secretary-ships, fourteen were held by British officers and five by Indians. Of the former, twelve were expected to leave in 1947 and the replacements in most cases were going to be Indians. Another matter, which saw the Interim Government in 'fairly lively' action in the month of February, was the question of the post of Indian High-Commissioner in the UK and its transfer from the Commerce Department to the External Affairs Department. While Nehru and Chundrigar both agreed that the incumbent Samuel Ranganathan had to go, they differed on the new appointment. ${ }^{127}$ The League wished to reopen a decision taken in October, before it had joined the cabinet that trade and consular representatives, including the Indian High-Commissioner in London, should be found from the new Foreign Service, under the enlarged and amalgamated department under Nehru. R.N. Banerjee recalled this episode in a manner that captured all the ambiguities of that interim era well: 'Chundrigar, and Liaquat Ali Khan fought very ably seconded by their Secretary, N.R. Pillai. The Commonwealth Relations Department's case was not put forward so vigorously... but for Matthai and Rajagopalachari coming to the rescue..., ${ }^{128}$

From mid-February 1947, budget proposals over-shadowed all else in matters of governance, while Prime Minister Clement Attlee's 20 February announcement of British withdrawal from India by June 1948, along with a change of viceroys, dominated political proceedings. To meet the aforementioned deficit, the Finance Department had proposed new taxes in the form of a Business Profits Tax 'estimated to produce thirty crores, increase of one anna in Corporation Tax to produce four crores, a changed super-tax to produce more than two crores, a Dividend Tax and a Capital Gains Tax (equivalent to a tax on unearned increment) to produce more than three crores'. Liaquat also proposed a 'high-powered tribunal to deal with

\footnotetext{
${ }^{127}$ Wavell to Pethick-Lawrence, 12 Feb. 1947, L/PO/10/24, IOR, BL.

${ }^{128}$ Oral History Transcripts, R.N. Banerjee (Acc. no. 366), p. 106, NMML.
} 
tax evasion'. ${ }^{129}$ This was a follow-up to the Prevention of Corruption Bill, 1946, which had been presented in the assembly by Patel in October.. ${ }^{130}$ On 17 February, after discussing a variety of Home and Information and Broadcasting matters with a 'pleasant' Patel, viz. 'the slowness of HMG in dealing with the question of the services, situation in the Punjab, question of language on the All-India Radio, [and] enquiries into the Calcutta and Bihar riots', Wavell discussed the budget proposals with Nehru, Liaquat and Matthai. ${ }^{131}$ The underlying idea behind the proposals, as Matthai agreed was that the Excess Profits Tax had been removed 'too early and it was necessary to find fresh taxes in view of the large deficit'. During his tenure at the Finance Department, he too had sought 'sources of revenue [as] industrial profits were still ruling high and large-scale evasion was still [on]'... 132

Wavell's last cabinet meeting before Attlee's announcement was on 19 February 1947. It was long and many items - tariffs on bicycles and woodscrews, regulation of dentists, note by Nehru on scientific manpower - 'went almost hilariously'. Next day, time was called on Wavell's tenure and a farewell mood descended. A 'sorry' Liaquat, 'polite' Nehru, 'perturbed' Baldev and 'nice' Rajagopalachari and Azad met or wrote to him, ${ }^{133}$ and, made the remainder of his cabinet meetings so 'friendly' that he wrote in his diary thus: 'one would never imagine from the atmosphere of discussion that each side was demanding the withdrawal of the other'. ${ }^{134}$ Instead, the two sides approved together the withdrawal of Indian soldiers from Egypt and Palestine immediately, retention of 8,000/14,000 troops in Iraq for 'guarding the

\footnotetext{
${ }^{129}$ Moon (ed.), Wavell, 12 Feb. 1947, p. 419.

${ }^{130}$ See File No. F.8/47-R, 1947, NAI.

${ }^{131}$ Moon (ed.), Wavell, 17 Feb. 1947, p. 421 and Wavell to Pethick-Lawrence, 19 Feb. 1947, L/PJ/10/77, IOR, BL.

${ }^{132}$ Matthai manuscript, pp. 1-8, NMML.

${ }^{133}$ Moon (ed.), Wavell, 19-20, 21 and 23 Feb. 1947, pp. 422-3.

${ }^{134}$ Moon (ed.), Wavell, 26-27 Feb. 1947, p. 424.
} 
stores at the Shiba base', withdrawal of 10,440 Indian occupation force from Japan as soon as possible and the return of troops from Burma and Malaya, 'at their convenience'.. 135

\section{February-March 1947: The Crisis Breaks}

The Interim Government's budget, which Liaquat presented on 28 February 1947 has been subject to much adverse comment, more for its ill-alleged politics than its well-articulated economics. ${ }^{136}$ As Azad put it in his memoirs: 'We were not against Liaquat Ali's proposals in principle [but] having secured [our] assent, he proceeded to frame [extreme] specific measures.... ${ }^{137}$ On 5 March, with the Congress party primed for Punjab's Partition, ${ }^{138}$ Nehru, Patel and Bhabha sent in minutes, dissenting from the record of the cabinet meeting of 28 February. It appeared to Wavell that the Congress was now 'trying to rat or hedge' in the face of the budget's unpopularity with its 'big business supporters'.. ${ }^{139}$ Sarvepalli Gopal would claim in his privileged biography of Nehru that 'Liaquat introduced a wide-ranging budget without full discussions with his colleagues or even Jawaharlal on at least the general nature of his proposals'.. ${ }^{140}$ In contrast, Matthai recalled agreeing 'with Liaquat that the 1947 budget must proceed on the basis that war conditions still persisted...Nehru agreed in the view I took'. Elaborating, Matthai felt that

In the way the tax proposals were embodied in his speech, Liaquat seemed to assume the role of a Tribune of the People against the oppressors of the poor...In the conditions of

\footnotetext{
13526 Feb. 1947, File No. 114/CF/46, Cabinet Secretariat, NAI.

${ }^{136}$ See chapter 3, 'Liaquat Ali Khan's 1947 Budget and the Corporate Response' in Nasir Tyabji, Forging Capitalism in Nehru's India: Neocolonialism and the State, c. 1940-1970 (Delhi: OUP, 2015). ${ }^{137}$ Maulana Abul Kalam Azad, India Wins Freedom (Hyderabad: Orient Longman, 1988), pp. 188-90. 138 Gyanendra Pandey, Remembering Partition: Violence, Nationalism and History in India (Cambridge: CUP, 2001), p. 31.

${ }^{139}$ Moon (ed.), Wavell, 5 Mar. 1947, p. 425.

${ }^{140}$ S. Gopal, Jawaharlal Nehru: A Biography Volume One, 1889-1947 (London: Jonathan Cape, 1975), p. 341.
} 
early-1947 the taxes were logically justified but viewed against the romantic background of the budget speech produced a psychological impression. ${ }^{141}$

From another vantage, H.M. Patel (ICS, 1927), the then-secretary to the interim cabinet, recollected being 'surprised at the subsequent developments because special care was taken by us to explain to everybody the practice in regard to the budget... and, no major objection was taken by anybody'. He continued that 'there was no real serious justification for the Congress to have made such a big issue... There was [nothing] that could be taken as attack on Hindu commerce'. ${ }^{142}$ Wavell's thoughts, as telegrammed to Pethick-Lawrence, were thus:

Liaquat's budget-considerable deficit-unanswerable justification for heavy taxationappeals to the Socialist in the Congress-popular support from all parties-Nehru and Matthai had accepted the proposals but Birla's HT [Hindustan Times] has voiced the outcry of millionaires-comment in the assembly largely on non-party lines-the budget is also a blow to British interests.. ${ }^{143}$

This last point was repeatedly made on the floor of the assembly by European members, who charged the budget of having 'a social objective to soak the rich', which would produce 'industrial insecurity' and kill the 'industrial goose that lay the golden eggs by 25 percent taxation'. On 4 March 1947, Matthai defended the budget thus: 'a popular government assuming power for the first time could not risk the repercussions...that deficit budgets bring'. It has since been called 'the first confrontation between the newly emerging state and the Indian capitalist class, which was striving hard to establish itself as the most important force in India within the power structure of the state'.. ${ }^{144}$ With Liaquat prepared 'to fight to the last ditch', 145 taxation proposals and investigation commission bill were referred to the Select Committee,

\footnotetext{
${ }^{141}$ Matthai manuscript, pp. 1-8, NMML.

${ }^{142}$ Oral History Transcripts, H.M. Patel (Acc. no. 90), pp. 10-1, NMML.

${ }^{143}$ Wavell to Pethick-Lawrence, 5 Mar. 1947, L/PJ/10/78, IOR, BL.

${ }^{144}$ Raghabendra Chattopadhyay, 'Liaquat Ali Khan's Budget of 1947-48: The Tryst with Destiny', in Social Scientist, Vol. 16, no. 6/7 (1988), pp. 77-89, p. 86.

${ }^{145}$ Liaquat to Jinnah, 13 Mar. 1947, item no. 124, in Z.H. Zaidi (ed.) Jinnah Papers First Series, Vol. I, Part I (Islamabad: Quaid-i-Azam Project, National Archives of Pakistan, 1993), pp. 237-8.
} 
which produced a compromise by reducing the proposed tax on business profits over Rs100,000 from twenty-five percent to sixteen percent. ${ }^{146}$

Wavell's last cabinet meeting was held on 19 March 1947 and was dominated by the INA case. He pre-empted his colleagues by announcing his 'intention to overrule, in the light of [Auchinleck's] views on the effect on morale of the army', their assent for the release of the prisoners. Nehru told him that his decision 'would have serious consequences'. ${ }^{147}$ Afterwards, he wrote a long letter to Pethick-Lawrence summing up the position on the budget and the situation in the cabinet: 'It is a difficult business and expose the unreality of our "coalition". ... 148 Next day, he gave a 'farewell dinner' to his colleagues, where he 'gathered from Liaquat that compromise on the budget [was] possible'. The departing Viceroy's last official meeting was with his Finance Member on 22 March 1947, in which they agreed to the select committee's suggestion, pending Congress' support. ${ }^{149}$ Upon his return to London, at the cabinet's India and Burma Committee, Wavell gave the following two-line review of the Interim Government: 'Proceedings in the Cabinet had been conducted in a friendly, good-humoured and practical manner. This, however, had not drawn the Congress and Muslim League closer together'. 150

\section{Conclusion}

And, so it was, but even the above synoptic survey of the priorities and policies of the Interim Government shows it to be far from all that it has been perceived as: a 'paralysed farce' or a

\footnotetext{
${ }^{146}$ See File No. L/E/8/5502, IOR, BL.

${ }_{147}$ Moon (ed.), Wavell, 19 Mar. 1947, p. 431.

${ }^{148}$ Wavell to Pethick-Lawrence, 19 Mar. 1947, L/PJ/10/78, IOR, BL.

${ }^{149}$ Moon (ed.), Wavell, 20-22 Mar. 1947, pp. 431-2.

${ }^{150}$ IB (47) $16^{\text {th }}$ Meeting, 28 Mar. 1947, L/PJ/10/78, IOR, BL.
} 
'prelude to Partition'.. ${ }^{151}$ Notwithstanding its over-remarked personal antagonisms and ideological oppositions, the Interim Government was far from being unworkable and needs to have its peculiar synthesis reflected upon and its legacies in the panorama beyond Partition remarked about. ${ }^{152}$ Headed by a British viceroy, participated by two and half Indian political parties and propped up by the British Indian civil service/army, the Interim Government was a unique landmark in the history of modern India. It was an intermediate passage between the 'new' of nation-building and the 'old' imperial legacies that needs to be investigated separately. It might not have been a crowning achievement of unity and fraternity but it was certainly an alternative attempt at sharing and exercising power, plagued as it was by rival tensions of grassroots pressure on the Congress and the League. In the 'advance' towards independence/Partition, it was an inter-party, inter-provincial and inter-departmental impulse of 'consolidation'. Colonial state apparatus' gradualism and caution met with impatient and self-determining urges of postcolonial society on the turf of the Interim Government; as did the politics of Partition with the activities of the Interim Government. At a time of collapse of intercommunal relations, it struggled valiantly as the State before Partition in a multiplicity of roles, during a phase of transition. This fluid transitory-ness in inadequately captured by the firm historiography of the period and further hints at a nuanced appreciation of this entire complex encompassing late-1940s. The Interim Government represented a juxtaposition relative to the perceived inevitability of Partition; a Borgesian 'garden of forking paths'. The stressed 'hybrid' that it was, it proved to be the apotheosis of 'high politics'.

\footnotetext{
${ }^{151}$ See Michael Brecher, Nehru: A Political Biography (Oxford: OUP, 1959), Penderel Moon, Divide and Quit (Berkeley: University of California Press, 1962), p. 60 and Anita Inder Singh, The Origins of the Partition of India, 1936-1947 (Delhi: OUP, 1987), p. 203.

${ }^{152}$ Here, I mean its post-1947 namesake - a similarly 'hybrid' arrangement.
} 